\title{
Optimization of Post-Tensioned Box Girder Bridges with Special Reference to Use of High-Strength Concrete Using AASHTO LRFD Method
}

\author{
Byungik Chang, ${ }^{1}$ Kamal Mirtalaei, ${ }^{2}$ Seungyeol Lee, ${ }^{3}$ and Kenneth Leitch ${ }^{1}$ \\ ${ }^{1}$ Department of Engineering and Computer Science, West Texas A\&M University, WTAMU Box 60767, Canyon, TX 79016, USA \\ ${ }^{2}$ Engineering Technical Group, Arizona Department of Transportation, 205 South 17th Avenue, MD 618E, Phoenix, AZ 85007, USA \\ ${ }^{3}$ Design Section, Nfra Inc., 77 E. Thomas Road, Suite 200, Phoenix, AZ 85012, USA
}

Correspondence should be addressed to Byungik Chang, bchang@wtamu.edu

Received 9 January 2012; Revised 17 May 2012; Accepted 24 May 2012

Academic Editor: Sami W. Tabsh

Copyright (C) 2012 Byungik Chang et al. This is an open access article distributed under the Creative Commons Attribution License, which permits unrestricted use, distribution, and reproduction in any medium, provided the original work is properly cited.

\begin{abstract}
With the Federal Highway Administration-mandated implementation of the LRFD specifications, many state departments of transportation (DOTs) have already started implementing LRFD specifications as developed by the AASHTO. Many aspects of the LRFD specifications are being investigated by DOTs and researchers in order for seamless implementation for design and analysis purposes. This paper presents the investigation on several design aspects of post-tensioned box girder bridges designed by LRFD Specifications using conventional or High-Strength Concrete (HSC). A computer spreadsheet application was specifically developed for this investigation. It is capable of analysis, design, and cost evaluation of the superstructure for a cast-in-place posttensioned box girder bridge. Optimal design of a post-tensioned box girder is achievable by correct selection of design variables. Cost evaluation of superstructures with different geometrical and material configurations has led to the development of optimum design charts for these types of superstructures. Variables used to develop these charts include, among others, span length, section depth, web spacing, tendon profile, and concrete strength. It was observed that HSC enables the achievement of significantly longer span lengths and/or longer web spacing that is not achievable when using normal strength concrete.
\end{abstract}

\section{Introduction}

American Association of State Highway and Transportation Officials (AASHTO) standard specification [1] has been the main bridge design specification in the United States since the 1940s. During the last two decades, there have been significant developments in concrete bridge design methods and utilization of new concrete materials. The implementation of load and resistance factor design (LRFD) and the use of High Strength/High Performance Concrete (HSC/HPC) are important subjects of investigation. The state DOTs have increased the use of HPC/HSC concrete and implementation of the AASHTO LRFD specification [2]. LRFD is based on the latest developments in structural analysis and materials to assure desired serviceability and ultimate behavior, safety, aesthetics, and economy. It benefits the valuable experiences of AASHTO allowable stress design (ASD) and load factor design (LFD) methods, which have been in use since the 1940s and comprise the Standard specification.

This new specification resulted in design procedures significantly different compared to the earlier methods. The new LRFD specification is based on a probability-based approach in which load and resistance factors are based on a specific level of structural failure [3]. The changes in the new LRFD design methods are significant and challenge the bridge engineers working with standard specification for so many years.

In the present work, a detailed investigation was performed on different aspects of cast-in-place (CIP) posttensioned box girder bridges. These include a general comparison of the two design specifications, utilization of post-tensioned high-strength concrete and cost based design optimization of the prestressed box girder bridges. A comprehensive spreadsheet was developed which enables 


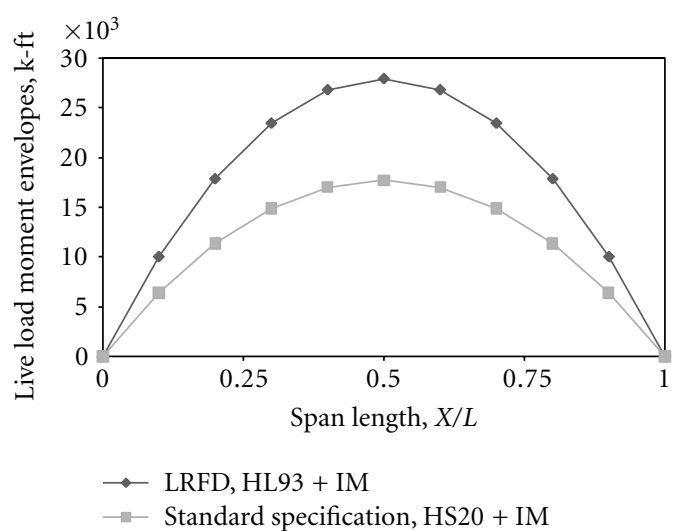

Figure 1: Comparison of moment envelopes due to only distributed live load plus impact for $180 \mathrm{ft}$ single-span box girder with eight webs spaced at $9 \mathrm{ft}$.

the user to input almost every necessary design parameter and perform the analysis, design, and cost estimate of a posttensioned box girder bridge superstructure according to both AASHTO standard and LRFD specifications. A copy of the program is obtainable by contacting the authors.

\section{Design Comparison}

Different design parameters were studied for the comparison of the newer LRFD and the older standard AASHTO specifications. These include live load bending moment and shear force envelopes, service and factored bending and shear envelopes, bending capacity, moment and shear distribution factors, prestressing losses, designed number of prestressing strands, and superstructure cost.

2.1. Live Load and Load Combinations for Moments. LRFD HL-93 live load is by itself significantly heavier than the standard HS-20 loading, but this difference will partly offset by the introduction of completely new live load distribution methods, service, and ultimate load factors. Figure 1 shows live load bending moment envelopes for HL-93 and HS20 (live load plus impact effects) which was calculated based on the whole cross-section, $55 \mathrm{~m}$ ( $180 \mathrm{ft}$ ) single-span box girder with eight webs spaced at $2.75 \mathrm{~m}(9 \mathrm{ft})$. According to the figure, an approximate $70 \%$ increase in moment is observed with the LRFD HL-93 live load.

When the combined effect of live and dead loads is considered, two different service load combinations (service I and service II) are used in LRFD method when allowable compressive and tensile stresses need to be checked in prestressed concrete members. Figure 2(a) compares all three cases, showing that moments by the LRFD method are very close to that of standard specification (approximately $9 \%$ and $4 \%$ increases for Service I and II, resp.)

(i) standard specification service $D L+(L L+I)$.

(ii) LRFD service I $D L+(L L+I), \quad 9 \%$ increase in moments compared to standard.

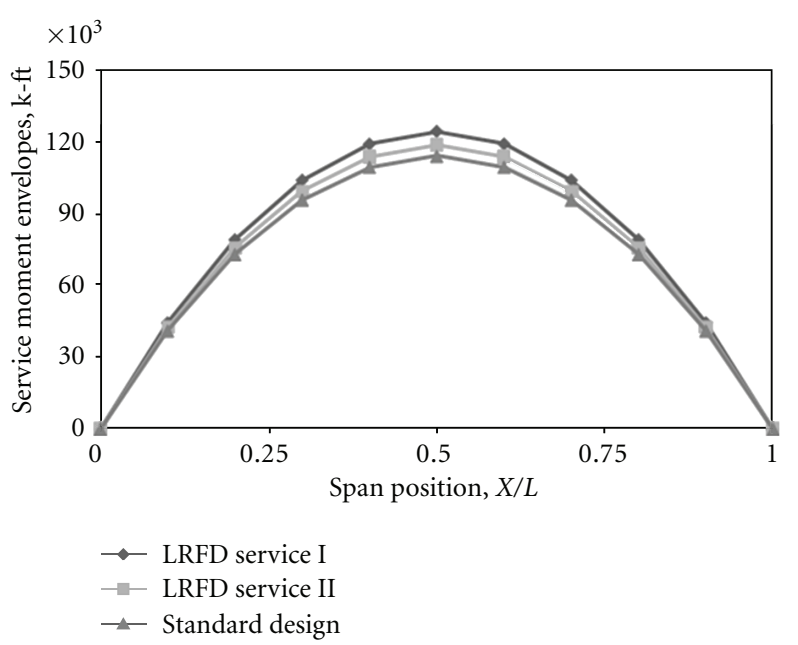

(a) Service load conditions

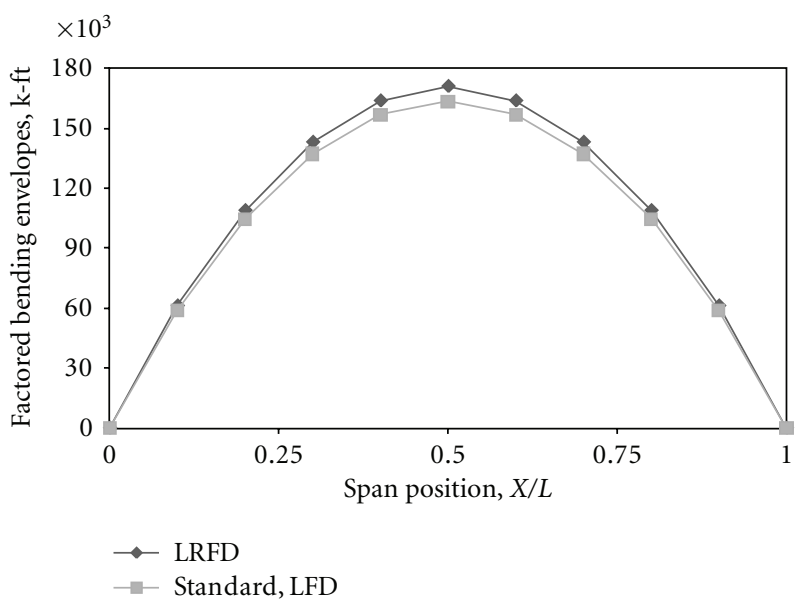

(b) Due to factored loads (strength I was considered for LRFD and LFD)

Figure 2: Comparison of moment envelopes for $180 \mathrm{ft}$ single-span box girder with eight webs spaced at $9 \mathrm{ft}$.

(iii) LRFD service III $\quad D L+0.8(L L+I), \quad 4 \%$ increase in moments compared to standard.

This is because live loads are much smaller than dead loads in a concrete bridge, and the distribution factor is smaller for LRFD. These will significantly offset the effect of the large LRFD HL-93 live load. The ultimate moment envelope combinations for standard design and LRFD specifications were also compared, and the results are shown in Figure 2(b). The following shows the load combinations:

(i) standard specification LFD combination: $M_{u}=$ $1.3\left(M_{D}+1.67 M_{D+I}\right)=1.3 M_{D}+2.17 M_{L+I}$,

(ii) LRFD load combination: $M_{u}=1.25 M_{D}+$ $1.75 M_{L+I} \quad$ (approximately $4 \%$ increase).

According to formulas shown above, standard design method gives higher-load factors and smaller-distribution factors as compared to LRFD. These will significantly offset the effect of higher LRFD HL-93 live load. 


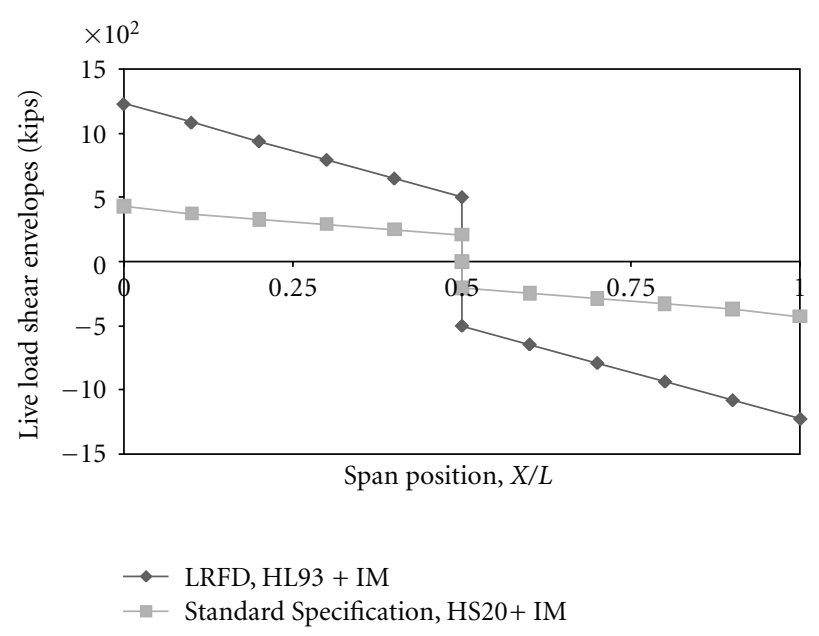

(a) Due to distributed live load plus impact

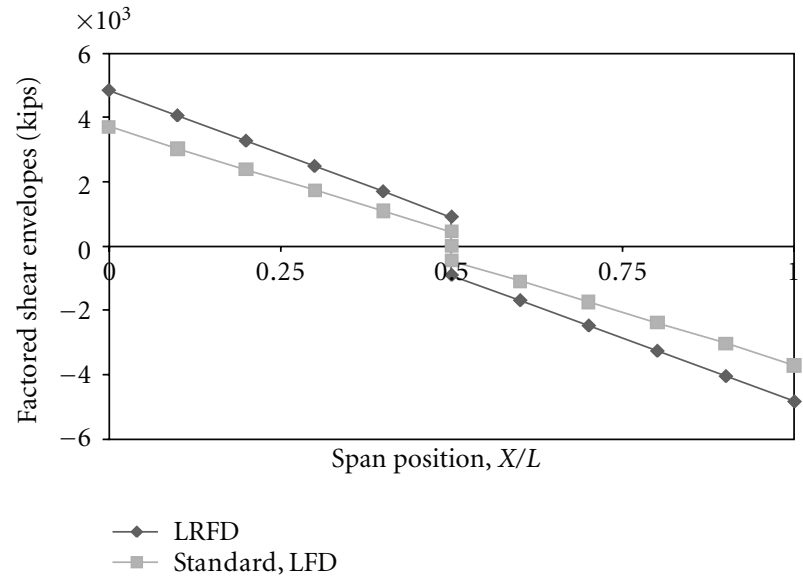

(b) Due to factored load

Figure 3: Comparison of shear force envelopes for $180 \mathrm{ft}$ single-span box girder with 8 webs spaced at $9 \mathrm{ft}$.

2.2. Live Load and Load Combinations for Shears. In case of the live load shears, it is seen that LRFD gives a significantly higher shear force (up to $180 \%$ of those for the standard specification) as shown in Figure 3(a). This is because the LRFD shear distribution factor is significantly larger than the one in standard specification. Factored shears are compared in Figure 3(b) and the figure shows an approximately 30\% increase in the use of the LRFD specification.

2.3. Distribution Factors. Live load distribution is one of the most important factors for a bridge design and the evaluation of existing bridges, and it has been the basis for design for several decades. The standard design specifications and LRFD specifications contain simplified methods to compute the live load effects. The new specification considers several structural properties of the bridge deck such as girder spacing, number of cells, and span length, and the examples are shown in (1) and (2) for LRFD and Standard, respectively, which shows how much the span length affects the factor.

$$
(\mathrm{DF})_{\mathrm{LRFD}}=\left(\frac{13}{N_{\mathrm{c}}}\right)^{0.3}\left(\frac{S}{5.8}\right)\left(\frac{1}{L}\right)^{0.25}
$$

for interior girders (two or more lanes),

$$
(\mathrm{DF})_{\text {Standard }}=\frac{S}{14}
$$

where $L$ is span length, $\mathrm{ft}, S$ is girder spacing, $\mathrm{ft}, N_{C}$ is number of cells, $N_{G}$ is number of girders $\left(N_{G}=N_{C}+1\right), L$ is span length, $\mathrm{ft}$, and $S$ is girder spacing, $\mathrm{ft}$.

Live load distribution is one of the most important factors for a bridge design bridge and for the evaluation of existing bridges, and has been the basis for design for several decades. The standard design specifications and LRFD specifications contain simplified methods to compute the live load effects. Extensive research work has been conducted for the live load distribution factors and for simplifying the equations [4-10].
Barr et al. [4] conducted an evaluation of flexural live load distribution factors for a series of three-span prestressed concrete girder bridges. In their work, the response of one bridge, measured during a static live load test, was used to evaluate the reliability of a finite-element model scheme. Bishara et al. [5] studied distribution factor expressions for wheel-load distribution to interior and exterior girders of concrete on multisteel beam composite bridges of medium span length. According to the work, the derived distribution factor expressions give values that are generally much lower than the current AASHTO values, particularly for skew bridges. In the National Cooperative Highway Research Program (NCHRP) Report 592 [9], the research provided live load distribution methods which are simpler than present LRFD methods, and hundreds of bridges were analyzed with finite element analysis and simplified methods. The LRFD equations were developed based on the NCHRP Project 12$26[10]$ and influenced a wide variation in modern bridge design.

A comparison of the distribution factors variation with span length can be seen in Figure 4. As shown in the figure, the LRFD predicts significantly lower values reducing with a span increase, while standard specification gives a higher value independent of span length.

2.4. Prestressing Steel Comparison. As discussed earlier, the LRFD live load (HL-93) is by itself significantly greater than the one compared to the standard specification live loading (HS20). For the design of prestressed members, it is considered in LRFD only $80 \%$ of the live load plus impact in its service III load combination (also refer to Figure 2). This load combination is specified only for the design of prestressed members when the tensile stress in the concrete needs to be checked. As an example, the designed number of strands for the same bridge using both methods is shown in Figure 5(a). The number of required strands in LRFD shows no significant difference with that of obtained by standard specification. This was examined for different girder 


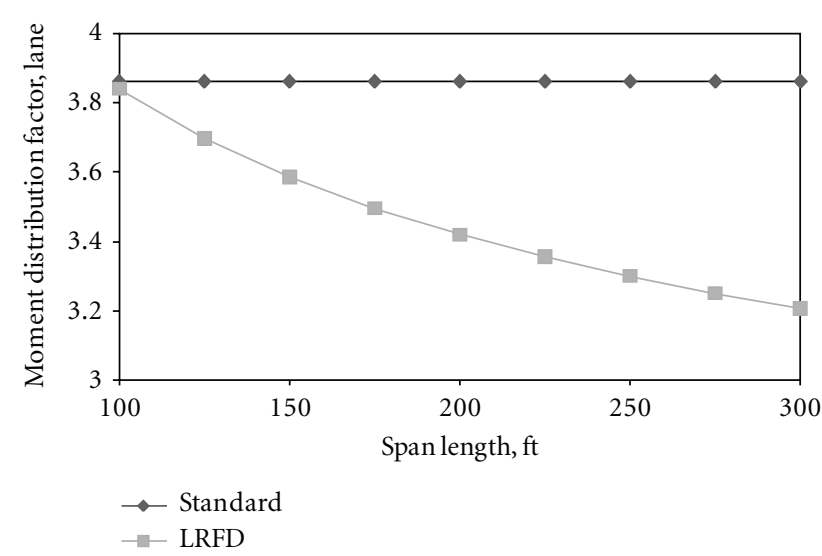

Figure 4: Moment distribution factors for a box girder (seven cells spaced at $9 \mathrm{ft}$ ) for standard and LRFD specifications.

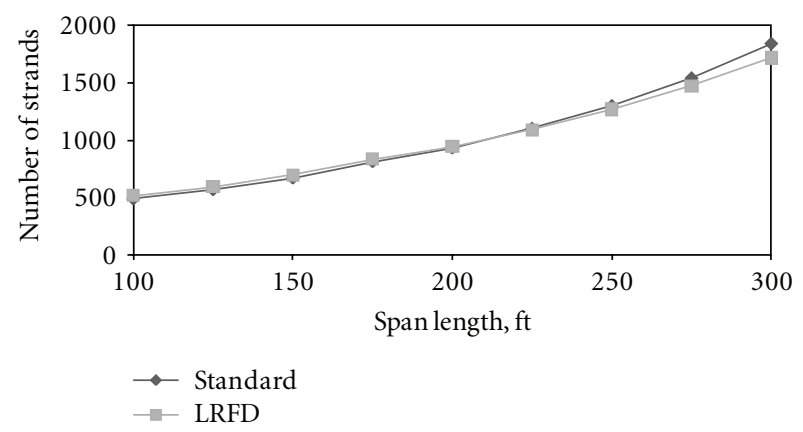

(a) Required number of strands

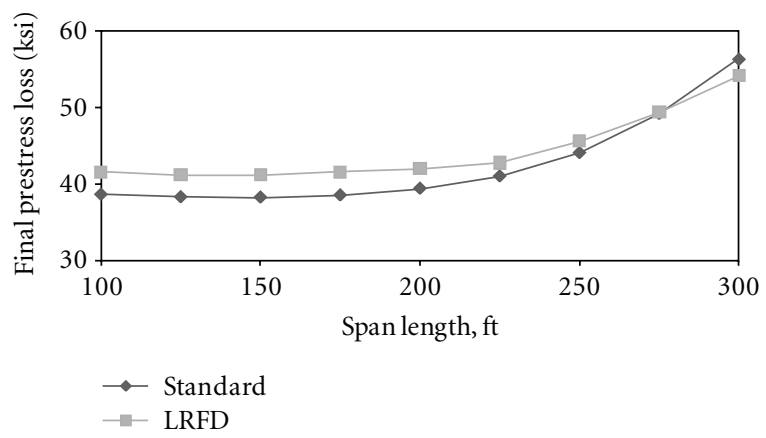

(b) Final prestress losses

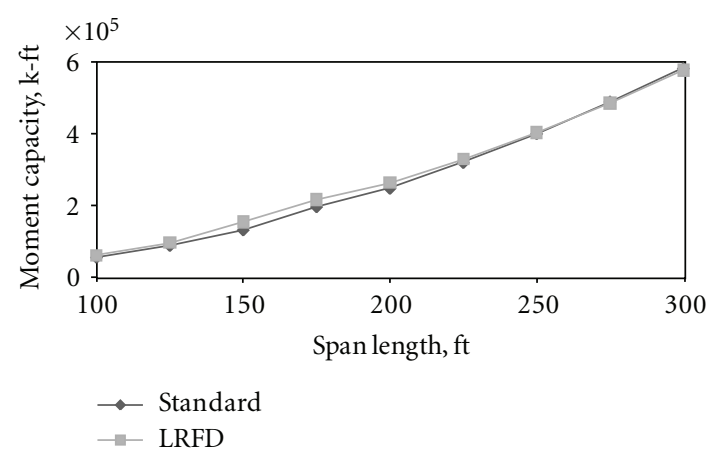

(c) Moment capacities

Figure 5: Comparison in box girder (seven cells spaced at $9 \mathrm{ft}$ ) for different span length. geometries and span lengths. It was also observed that the amount of extra steel strands required by LRFD is about 3 to $4 \%$ more as compared to the standard specification.

2.5. Prestress Losses. Apart from the new formulation for prestressing loss due to elastic shortening in LRFD-C5.9.5.2.3b [2], other loss calculations remain unchanged. Figure 5(b) shows a comparison of final prestress losses and that the final loss predicted by LRFD is approximately $6 \%$ more than the losses predicted by the standard specification.

2.6. Moment Capacity. Moment capacities were calculated in accordance with both standard specification and LRFD. The same formulation of standard specification for rectangular sections is used in LRFD. Other parameters mentioned previously have minor effects and the resulting moment capacities are very close as shown in Figure 5(c).

2.7. Superstructure Cost. Superstructure cost for posttensioned cast-in-place concrete box girder was calculated based on the cost estimates of similar recent projects in Arizona. Similar span-to-depth ratios, web and bottom slab thickness, and reinforcements were used for both methods. Differences in design parameters appeared to be the number of strands and deck reinforcements. The LRFD introduces two design methods for deck reinforcement, and the traditional method in this paper was used with slightly lower steel reinforcement. Among two methods, the total cost in standard specification is slightly lower when using LRFD (Figure 6).

\section{Web Spacing}

Web spacing $S$ is an important parameter affecting other design variables as follows:

(i) distribution factor (DF) is directly dependent on a value of $S$ for both methods, and as it is seen in Figure 7, LRFD predicts smaller moment distribution factors than standard (see (1) and (2));

(ii) top slab (deck) thickness and reinforcement are both dependent on web spacing;

(iii) superstructure weight is depending on the number of webs and top slab thickness;

(iv) prestressing steel area and superstructure cost are dependent on web spacing.

In the study of the effect of web spacing on other parameters, a box girder with $45.7 \mathrm{~m}$ ( $150 \mathrm{ft}$ ) span length and constant width of $30.5 \mathrm{~m}(100 \mathrm{ft})$ was considered. The web spacing varied from 1.83 to $5.18 \mathrm{~m}$ ( 6 to $17 \mathrm{ft}$ ). For each case, deck thickness, deck reinforcement, and prestressing strands were designed.

3.1. Optimum Web Spacing. The optimum web spacing for the box girder was considered to be the spacing for which the superstructure cost is minimized. Superstructure cost 


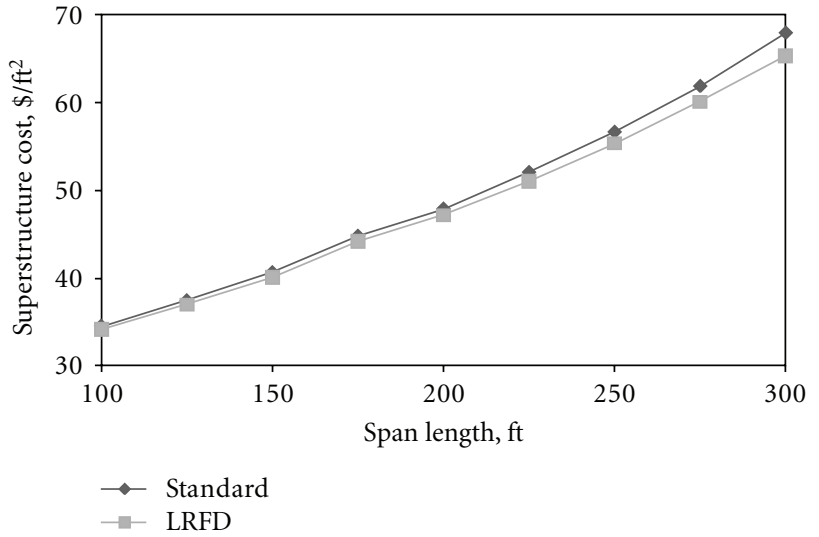

Figure 6: Superstructure cost, $\$ / \mathrm{ft}^{2}$ for a box girder (seven cells spaced at $9 \mathrm{ft}$ ).

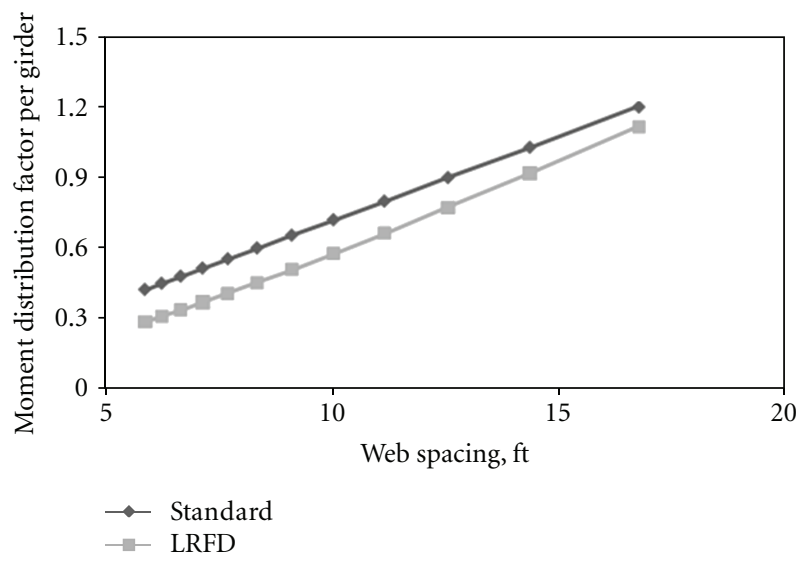

Figure 7: Distribution factors for box girder ( $150 \mathrm{ft}$ span, $100 \mathrm{ft}$ width, and varying web spaces).

was determined based on the cost estimates of recent similar project in Arizona. In the design process, all design constraints such as the maximum number of tendons and the maximum number of strands per tendon were considered. Any other design limitations set by the respective specifications were also considered as a constraint. Web and bottom slab thicknesses were assumed to be $30.5 \mathrm{~cm}$ (12 in.) and $15.2 \mathrm{~cm}$ (6 in.), respectively, for all design cases. The primary variable is web spacing, which will affect top slab depth, top slab steel, overall weight, prestressing steel, and shear reinforcement. As seen in Figures 8(a) and 8(b), two span lengths of $45.7 \mathrm{~m}(150 \mathrm{ft})$ and $54.9 \mathrm{~m}(180 \mathrm{ft})$ were considered for optimization process. In both cases, a minimum point can be observed on the curve corresponding to the optimum web spacing. For the $150 \mathrm{ft}$ span using LRFD method, the optimum spacing is about $3.35 \mathrm{~m}(11 \mathrm{ft}$ ) (see Figure 8(a)). For the standard specification, the optimum distance is slightly more. Considering the $180 \mathrm{ft}$ span (Figure 8(b)), the 0 minimum point is not well pronounced as it was in the previous case. Although the curve is rather flat in this region, an optimum spacing of about $3.66 \mathrm{~m}(12 \mathrm{ft})$ can still be observed.

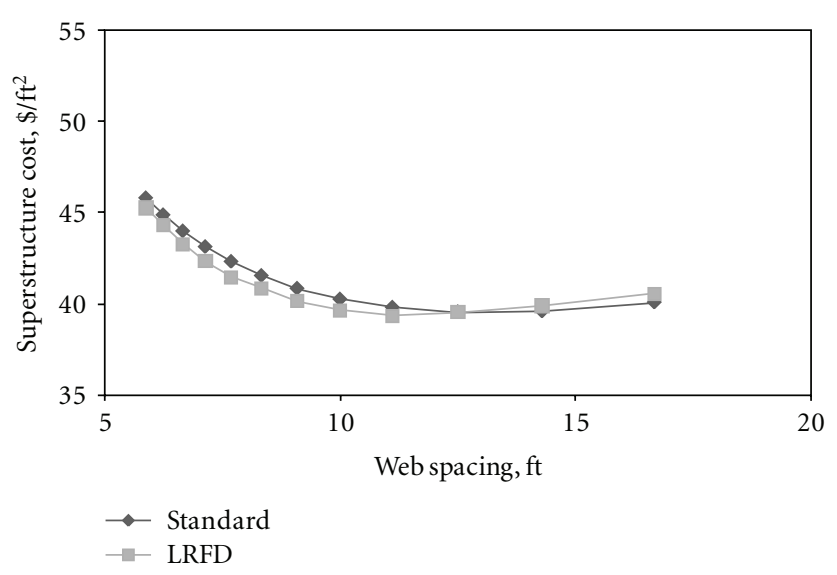

(a) Span of $150 \mathrm{ft}$ and width of $100 \mathrm{ft}$

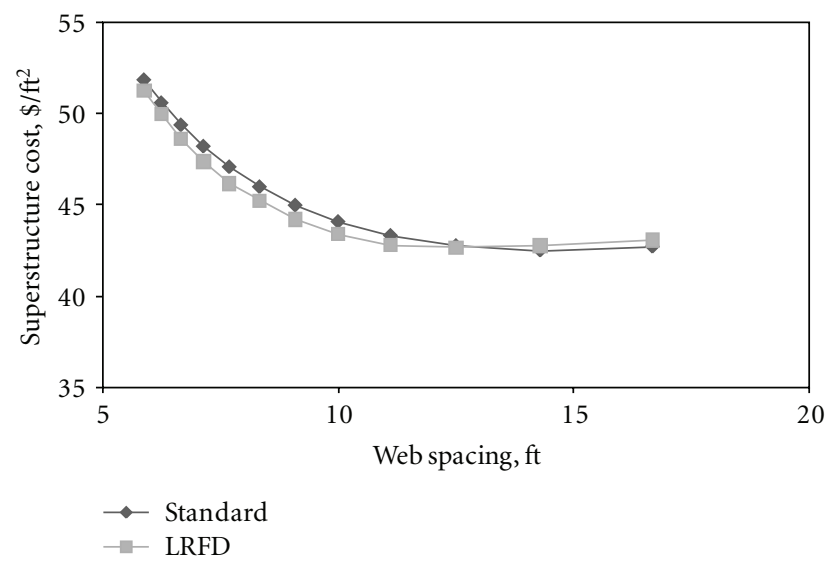

(b) Span of $180 \mathrm{ft}$ and width of $100 \mathrm{ft}$

Figure 8: Superstructure cost and optimum web spacing.

\section{Utilization of High-Strength Concrete in Box Girders}

The advantage of high-strength/high-performance concrete (HSC/HPC) has been well documented during the past 25 years. Most of the researches in this area address the importance of HPC/HSC to improve the concrete durability, physical properties (strength, creep, shrinkage, etc.) and concrete strength capacity when used as a structural member $[11,12]$. It is true that poor concrete quality and lack of durability rather than structural problems cause most damages to concrete structures. Myers and Yang [13] provide a comprehensive reference list of research in this area. Several structural features can be improved and/or economized by utilization of high-strength concrete [11]. These structural features are those which are significantly dependent on concrete strength.

4.1. HSC Effect on Prestressing Steel. The required amount of prestressing steel depends on the compressive and tensile strength of concrete. The allowable compressive stress is directly dependent on concrete strength, $f_{c}^{\prime}$, while the allowable tensile stress is proportional to the square root of concrete compressive strength. For calculation, it was assumed 


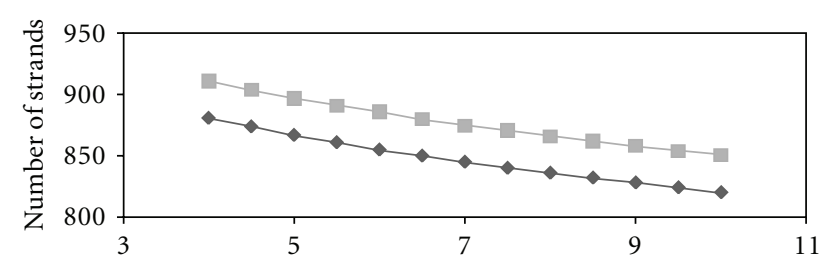

(a)

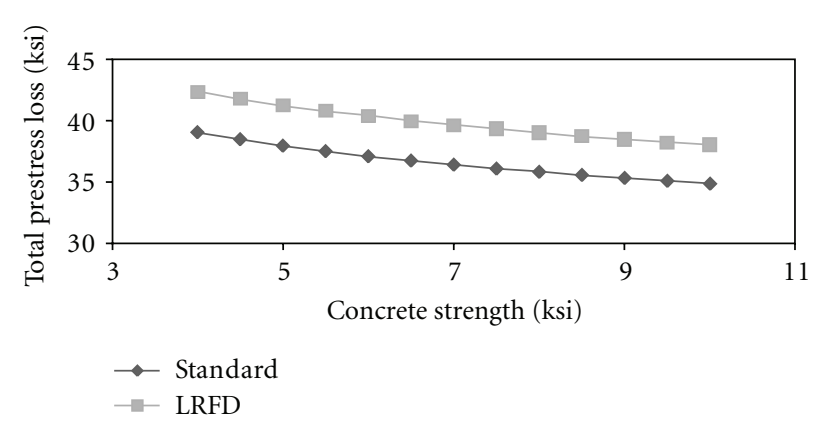

(c)

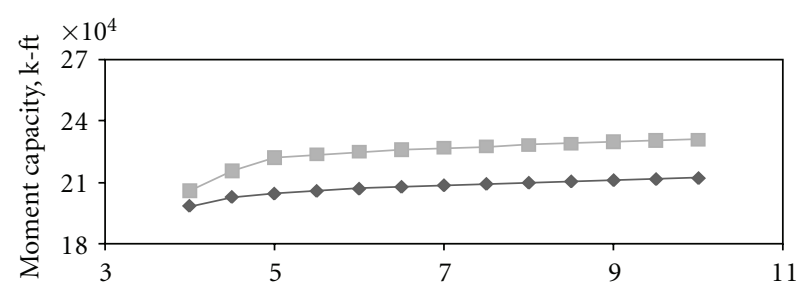

(b)

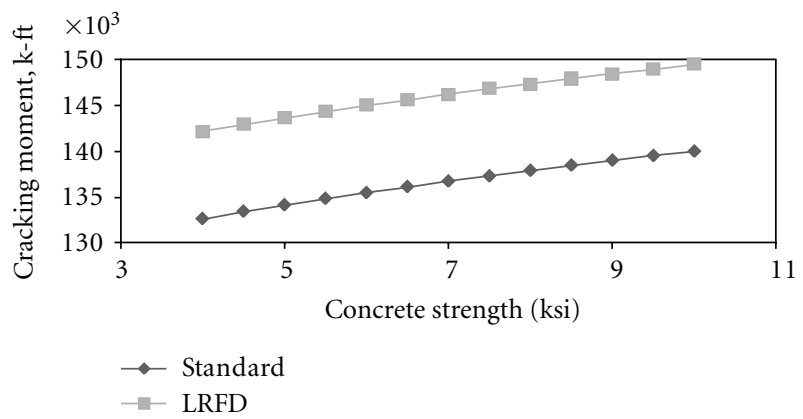

(d)

Figure 9: Effect of concrete strength for the span of $180 \mathrm{ft}$ and 8 webs spaced at $10 \mathrm{ft}$ : (a) on designed number of strands, (b) on moment capacity, (c) on final prestressing loss, and (d) on cracking moment.

that the compressive strength of the concrete at transfer is $85 \%$ of its final specified strength. For LRFD service III load combination (applied for concrete in tension), using a higher concrete strength is very helpful and provides more flexibility for the design engineer to control the stress limits within practical limitations (using specific girder geometry, web spacing, tendon profile, etc.). Similarly, for the release condition, higher concrete strength is very helpful when LRFD tensile and compressive stress limits need to be checked. Figure 9(a) shows how the number of strands decreases with an increase in concrete strength while the LRFD always requiring slightly more strands. For the special case considered, with every approximate $7 \mathrm{MPa}$ (1 ksi) increase in concrete strength, a saving of 20 strands was observed.

4.2. Ultimate Bending Capacity. Bending capacity of a flexural member is not sensitive to the concrete compressive strength. It is mainly dependent on the effective depth and the amount of steel used in the section. For the strength range from 24 to $35 \mathrm{MPa}$ ( 3.5 to $5 \mathrm{ksi}$ ), some increase in moment capacity can be seen (Figure 9(b)) in both methods. Considering the calculation process, it was observed that for the lower strength range, the shape of the compression zone (for moment capacity calculation) transitions from a " $T$ " to a rectangle. LRFD introduces a new formulation for the neutral axis depth of " $T$ " sections to obtain the bending capacity. For concrete strengths beyond $38 \mathrm{MPa}$ ( $5.5 \mathrm{ksi})$, the moment capacity will not change significantly. It is observed that there is a little decrease (about 1\%) in bending capacity with an increase in concrete strength from 35 to $70 \mathrm{MPa}$ (5 to $10 \mathrm{ksi}$ ). The reason for decrease is that while the concrete strength is increasing, there is slight reduction in the designed number of strands which in turn will reduce the moment capacity.

Furthermore, the number of strands was kept constant, and the effect of concrete strength was observed. A change of concrete strength from 35 to $70 \mathrm{MPa}$ (5 to10 ksi) will increase the moment capacity of the box section by only $4 \%$, which is still insignificant. The reason is that by increasing the concrete strength, the depth of compressive zone will slightly decrease to make the same compressive force (equal to the steel tensile force). As a result, we cannot solely rely on the concrete strength to improve the bending capacity of the section.

It is worth noting here that by using higher concrete strength, in fact the compressive strain capacity of concrete will increase (approximately from $0.3 \%$ to $0.5 \%$ ). This is a very good advantage, which provides more rotation capacity (and hence, ductility) for the section even though the moment capacity remains the same.

4.3. Loss of Prestress. Among several prestress losses, only elastic shortening and anchor set are dependent on the concrete modulus of elasticity, which can be improved when using high-strength concrete. The effect of concrete strength is not currently considered on creep and shrinkage of concrete, which are the two most important time-dependent parameters. It should be mentioned that a higher concrete strength may significantly reduce their effects in prestressed members. Figure 9(c) shows the effect of concrete strength on final prestressing loss.

4.4. Cracking Moment. The cracking moment depends on the tensile strength of concrete, which is in turn affected by compressive strength. An increase of 5\% in cracking moment 


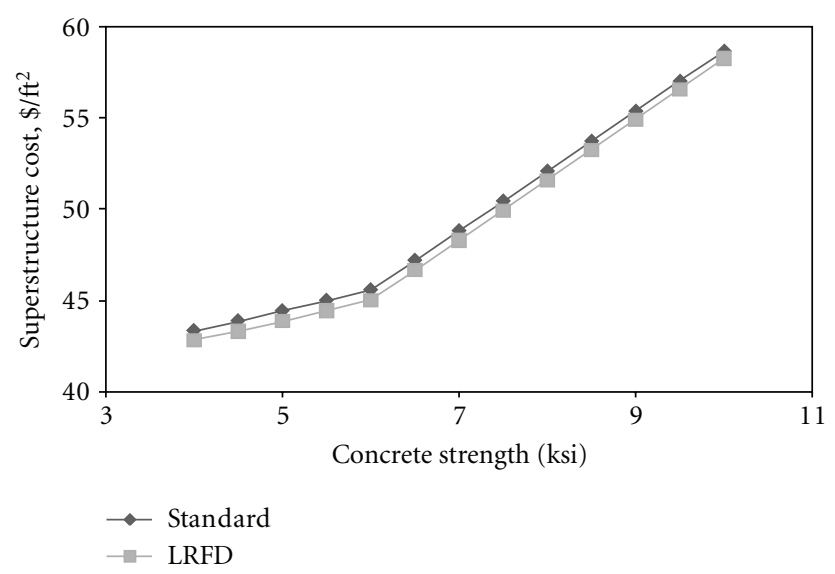

FIGURE 10: Approximate superstructure cost versus concrete strength.

may be predicted for concrete strengths changing from 35 to $70 \mathrm{MPa}$ (5 to $10 \mathrm{ksi}$ ) (see Figure 9(d)).

4.5. Superstructure Cost. Superstructure cost will be affected by the use of high-strength concrete. For high-strength concreted the rate of cost increase is higher compared to conventional concrete (Figure 10). Since there is not a high production capacity for high-strength concrete at the present time, the anticipated cost increase may be significant. Approximate cost increase can be at least $\$ 32 / \mathrm{m}^{2}\left(\$ 3 / \mathrm{ft}^{2}\right)$ of superstructure at a strength increment of $7 \mathrm{MPa}(1 \mathrm{ksi})$. This cost increase may not be justified only for structural improvements. Considering the inherent durability improvements when using high-strength concrete, there will be significant long-term saving in the project. As it was also seen before, the superstructure cost for LRFD is slightly less than that of the standard specification. The main reason was found to be reduced deck steel calculated with LRFD.

4.6. Increase of Span Length with Concrete Strength. In the process of prestressed concrete design, the most beneficial effect of high-strength concrete would be its higher tensile strength when using LRFD service I and service III load combinations. In this part, all the parameters were keep constant except concrete strength and the span length. Figure 11 shows the capability of concrete strength to stretch the bridge span, and Table 1 summaries the span lengths, concrete strength, and number of strands. The first two rows in the table indicate that for $51.2 \mathrm{~m}(168 \mathrm{ft})$ span length and $27.5 \mathrm{MPa}(4 \mathrm{ksi})$ concrete, 850 strands are required. If we keep the same number of strands and increase the concrete strength to $62 \mathrm{MPa}$ ( $9 \mathrm{ksi}$ ), the span length can be increased to $55 \mathrm{~m}$ (180 ft).Comparing second and third rows reveals that the design will need 60 strands less if $62 \mathrm{MPa}$ ( $9 \mathrm{ksi}$ ) concrete is used instead of $28 \mathrm{MPa}$ (4 ksi). A reduction in strands number is very helpful for condition in which the maximum number of strands per tendon becomes a controlling factor.

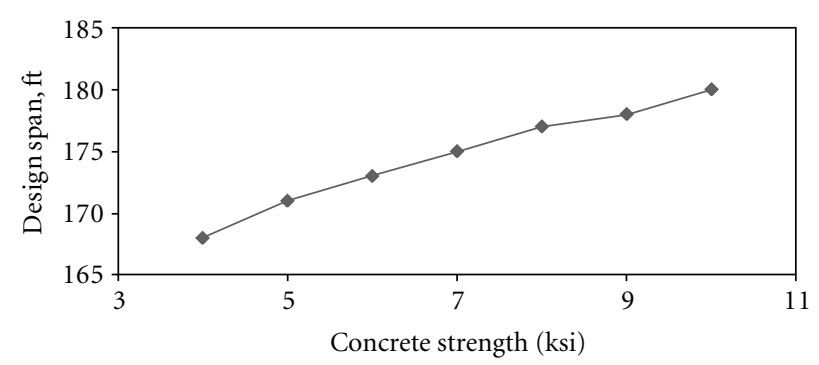

FIGURE 11: Span stretching by using higher concrete strength.

TABLE 1: Design summary.

\begin{tabular}{lcc}
\hline Span length, $\mathrm{ft}$ & Concrete strength, ksi & No. of strands \\
\hline 168 & 4 & 850 \\
180 & 9 & 850 \\
180 & 4 & 910 \\
168 & 9 & 800 \\
\hline
\end{tabular}

\section{Span-to-Depth Ratio}

Conventionally, a span-to-depth ratio of 0.045 is used for simple span concrete box girders. Based on experiences, it seems that the use of this ratio will ensure the control of deflection. In this part of investigation, the superstructure costs were observed for different span-to-depth ratios. As it is seen in Figure 12, the lowest cost is associated with a ratio of 0.05 . For example ( $150 \mathrm{ft}$ span), it means that an extra depth of $23 \mathrm{~cm}$ (9 in.) will lead to a saving of almost 100 strands.

\section{Conclusions}

Single-span cast-in-place post-tensioned box girders were analyzed and designed according to standard and LRFD specification. The primary objective was to compare all design parameters using theses specifications and also to perform some detailed parametric studies subjects such as geometrical optimization of the box girder section and structural utilization of high strength concrete (HSC). Comparison reveals that despite significant increase in live loads, other design parameters (distribution factors, load factors, and design methods) are observed as following:

Comparison of Standard and LRFD Specification. (1) The LRFD design needs slightly more (about $4 \%$ ) prestressing steel as compared to the Standard Specification.

(2) Predicted shear carried by the concrete is significantly lower when using LRFD method. This will lead to a greater stirrup requirement.

(3) Final prestressing loss is about $7 \%$ more for LRFD method.

(4) Superstructure cost is slightly lower for LRFD due to introduction of new method of moment calculation in the deck slab. 


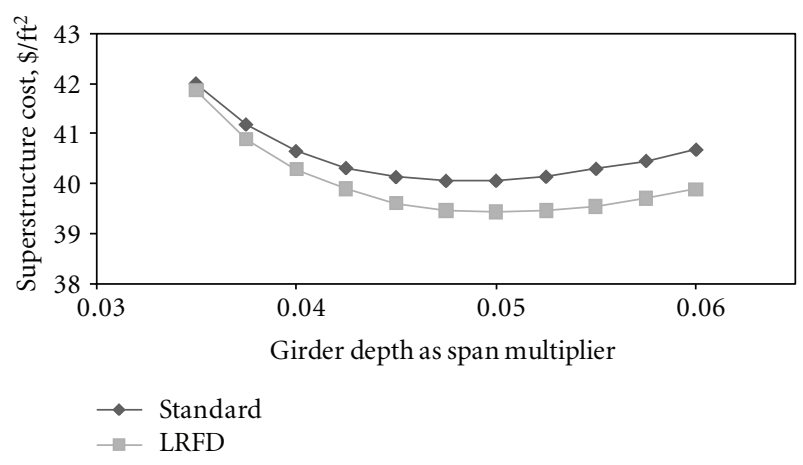

FIGURE 12: Effect of span-to-depth ratio on superstructure cost ( $150 \mathrm{ft}$ span, eight webs spaced at $10 \mathrm{ft}$ ).

Optimum Web (Girder) Spacing. (5) Cost analysis and comparison shows that when changing the girder spacing, there is always a minimum superstructure cost. The girder spacing associated with that minimum cost could be considered as the optimum spacing.

(6) The optimum web spacing can be based on minimum cost. It was found that for box girders with span lengths 46 to $55 \mathrm{~m}$ (150 to $180 \mathrm{ft}$ ), the optimum web spacing is 3.35 to $3.66 \mathrm{~m}$ (11 to $12 \mathrm{ft})$.

Structural Effect of High-Strength Concrete. (7) Higher concrete strength provides great flexibility for designers to utilize the maximum service load capacity for the specific girder section. This advantage may result in larger span length, smaller number of strands, or wider web spacing for the same section.

(8) Using higher concrete strength will reduce final prestressing loss and the number of strands. Moment capacity is not sensitive to concrete strength, except for lower strengths (less than $31 \mathrm{MPa}(4.5 \mathrm{ksi})$ ).

(9) Anticipated cost increase for superstructure is about $\$ 32 / \mathrm{m}^{2}\left(\$ 3 / \mathrm{ft}^{2}\right)$ for each $7 \mathrm{MPa}$ (1 ksi) increase in concrete strength.

Span-to-Depth Ratio. (10) Compared to the LRFD-recommended depth/span ratio of 0.045 , it was observed that the slightly higher ratio of 0.05 is more cost effective.

\section{References}

[1] AASHTO, Standard Specification for Highway Bridges, AASHTO, Washington, DC, USA, 17th edition, 2002.

[2] AASHTO, AASHTO LRFD Bridge Design Specifications, 2007 Edition and 2008 addendums, AASHTO LRFD, Washington, DC, USA, 2007.

[3] A. S. Nowak, "Calibration of LRFD bridge code," ASCE Journal of Structural Engineering, vol. 121, no. 8, pp. 1245-1251, 1995.

[4] P. J. Barr, M. O. Eberhard, and J. F. Stanton, "Live-load distribution factors in prestressed concrete girder bridges," ASCE Journal of Bridge Engineering, vol. 6, no. 5, pp. 298-306, 2001.

[5] A. G. Bishara, M. C. Liu, and N. D. El-Ali, "Wheel load distribution on simply supported skew I-beam composite bridges,"
ASCE Journal of Structural Engineering, vol. 119, no. 2, pp. 399-419, 1993.

[6] R. V. Nutt, T. Zokaie, and R. A. Schamber, "Distribution of wheel loads on highway bridges," NCHRP Project. no. 1226, National Cooperative Highway Research Program, TRB, Washington, DC, USA, 1987.

[7] T. Zokaie, "AASHTO-LRFD live load distribution specifications," ASCE Journal of Bridge Engineering, vol. 5, no. 2, pp. 131-138, 2000.

[8] T. Zokaie, T. A. Osterkamp, and R. A. Imbsen, "Distribution of wheel loads on highway bridges," Transportation Research Record 1290, Washington DC, USA, 1991.

[9] Bridge Tech, Inc., "NCHRP report 592: simplified live load distribution factor equations," Transportation Research Board, National Research Council, Washington, DC, USA, 2007.

[10] Bridge Tech, Inc., "NCHRP report 12-26: simplified live load distribution factor equations," Transportation Research Board, National Research Council, Washington, DC, USA, 2006.

[11] Z. P. Bazant and L. Panula, "Creep and shrinkage characterization for analyzing prestressed concrete structures," JournalPrestressed Concrete Institute, vol. 25, no. 3, pp. 86-122, 1980.

[12] S. H. Ahmad and S. P. Shah, "Structural properties of high strength concrete and its implication for precast prestressed concrete," Journal - Prestressed Concrete Institute, vol. 30, no. 6, pp. 92-119, 1985.

[13] J. J. Myers and Y. Yang, "Practical issues for the application of high-performance concrete to highway structures," ASCE Journal of Bridge Engineering, vol. 6, no. 6, pp. 613-627, 2001. 

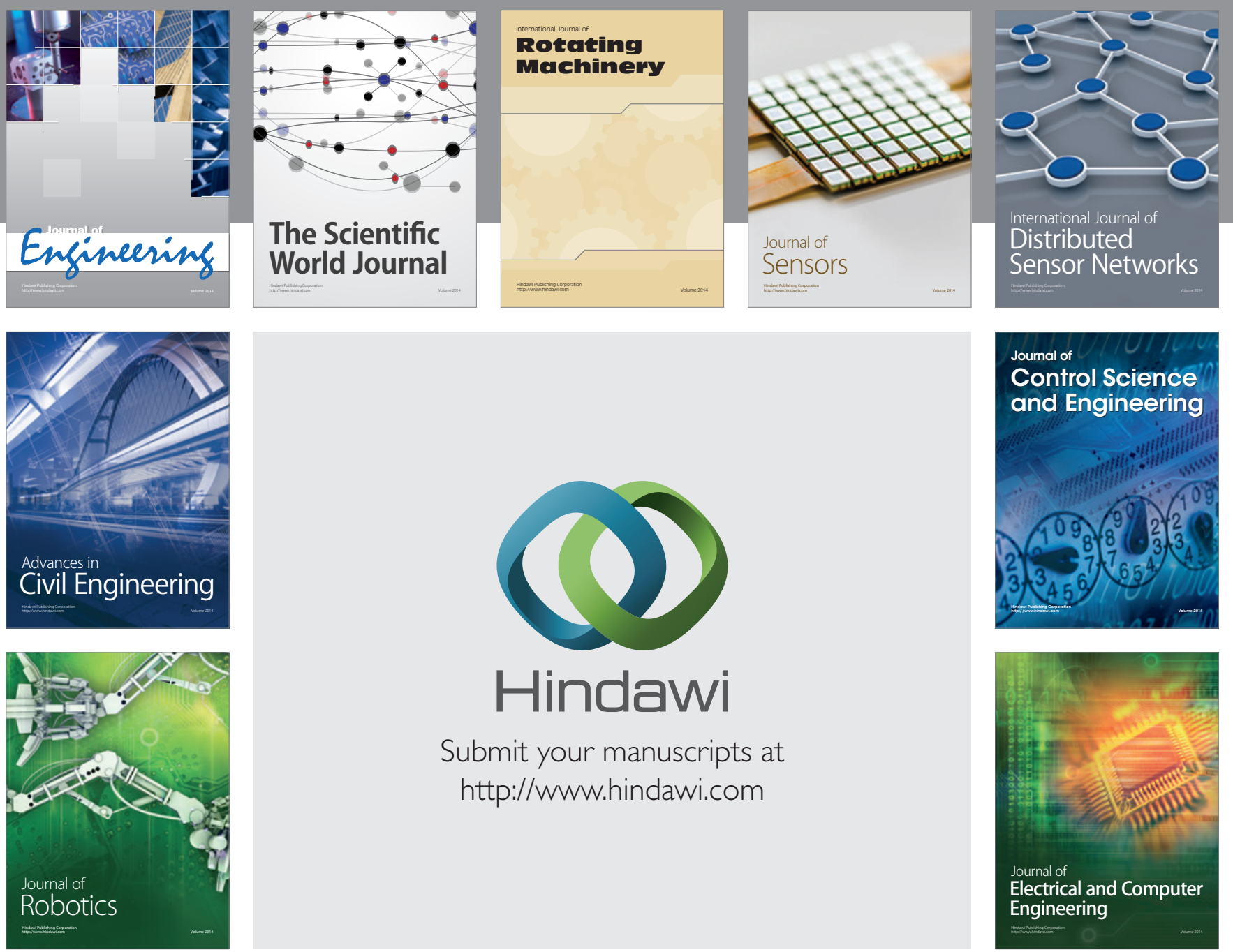

Submit your manuscripts at

http://www.hindawi.com
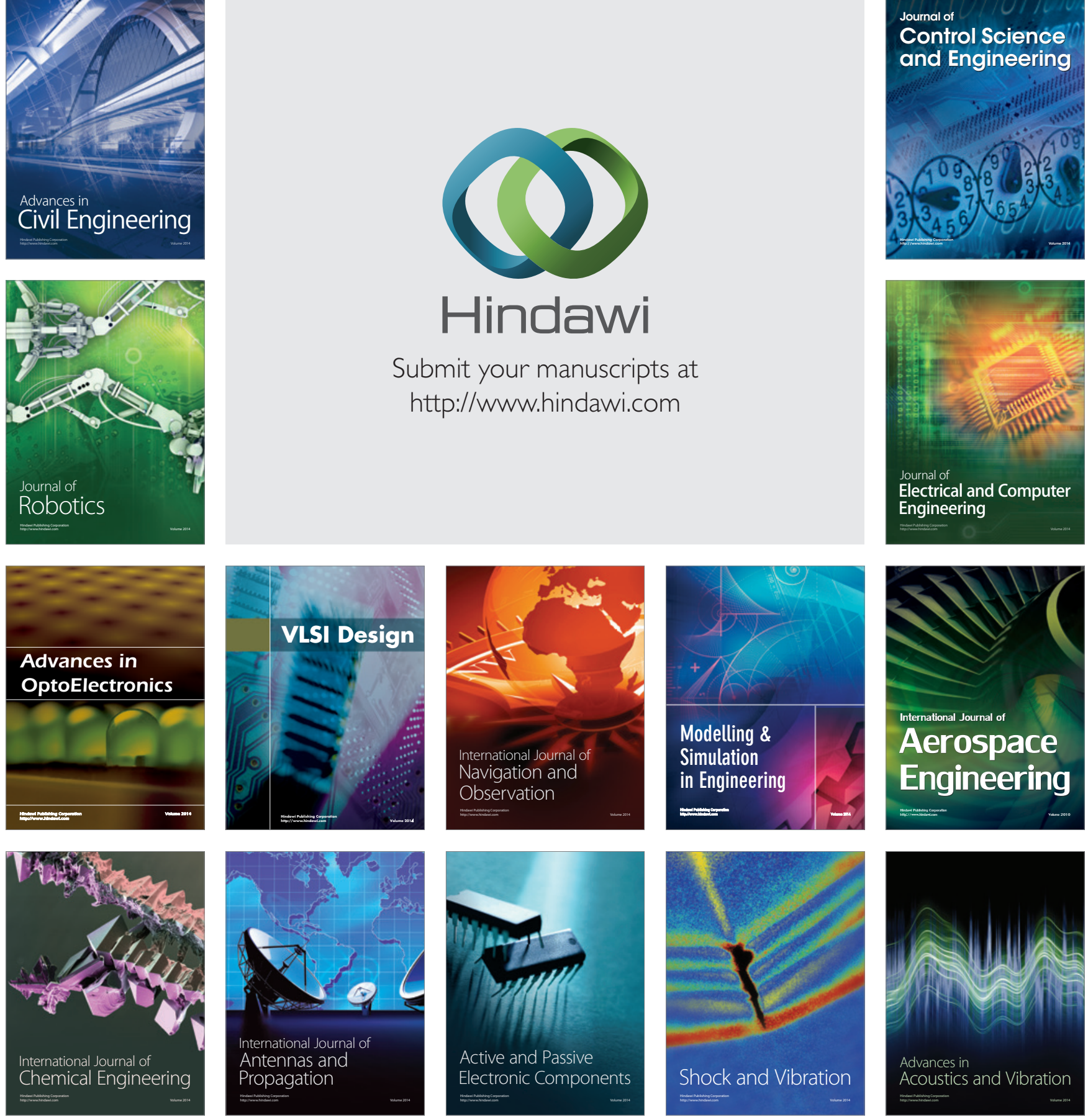